\title{
The definition of success in education and new approaches
}

\author{
Ülkü Gezer ${ }^{1 a}$ \\ Graphic Design Department, Fine Arts Faculty, Fatih Sultan Mehmet Vakıf University, \\ Istanbul, Turkey
}

\begin{abstract}
Do postmodern approaches replace the modern approaches while the classical approach is replaced by modern approaches in education? It seems that the changing needs of the societies lead to the creation of new paradigms. Our paradigms which derived from preexisting knowledge, experiences, and implied conditioning, constitute our 'way to perceive a situation' and manage our perspective which directs our behaviors. Thus, globalization, accelerating the flow of information through the internet network, should change the way we observe a situation and our perspective on education and educators. As a continuation of this, our point of view should change our behavior. Success is a combination of many factors mentioned above, which are related to each other. Hence, the study intends to examine the utmost prominent factors in the education systems that may be taken as an example and after comparing these factors with Turkey's status, the study intends to investigate which lessons could be taken from this knowledge.
\end{abstract}

Keywords: visual arts education, teacher, new

\section{Introduction}

There are continuous developments in science and technology. While these developments change the needs of the individuals and their lives, it reveals the necessity of educating the qualified human power that can catch the speed of new technology and the era in every way. In other words, it has become compulsory for countries to make innovation in the education strategies. Do postmodern approaches replace the modern approaches while the classical approach is replaced by modern approaches in education?

Since these approaches should also be contemplated in terms of educational strategies, are these strategies being considered and altered through in physical, principal and methodological context?

It seems that the changing needs of the societies lead to the creation of new paradigms. When thinking that way, we need first to investigate and reveal what are the problems among today's paradigms.

a Corresponding author: ulkugezer@gmail.com 
Thus, globalization and the acceleration of the flow of information through the internet network should change "the way we observe a situation" and our perspective on education and educators. As a continuation of this, our point of view should change our behavior. "In the third millennium, the countries all around the world are constantly renewing their education systems and are implementing reform practices with the objective of education more people for a longer time. Thanks to the use of new technologies, the 'individual competencies' that were important in the past lose their importance. The fast change observed in every area requires making innovations in the objectives of education, in the learning-teaching process, the period of study, and as well as in the competencies of the educators." [12]

Unfortunately, our current education system does not prepare students for citizen opportunities awaiting them in the $21^{\text {st }}$ century. Using skills such as communication, problem solving and creativity in real life is essential in every area. Young people will need to establish links between various sources of information and their forms of representation in the future. They will need to be able to contemplate deeply and use their judgment about their transactions. They will need to explain others their comments and their judgments. As it is obvious, the PISA results indicate unfortunately that the vast majority of young people in our country do not possess these skills. Thus, this would be challenging entering in the global competition in production, innovation, science, and art.

So, what is the secret of successful countries in PISA? "These are not totally new strategies, a new curriculum, a flexible structure, each school to define its own goal and vision, the education and selection of teacher and school administrators, giving importance to the preschool education." [4]

In this study, we examined the utmost prominent factors in the world after examining various education system that can be taken as examples and after comparing these factors with Turkey's status, this study intends to investigate which lessons could be taken from this knowledge.

The aim of this study is to address only the crucial points since we know that the comprehensive review and the development of proposals are primarily the duty of educational scientists.

We prioritized the immediate approaches that may be applied today like asking the right questions and to make appropriate determinations as an educator.

We may evaluate the development of a country by investigating its education system. In other words, when we analyze various countries in the world, it is possible to say that there is a proportional relationship between the education systems and the development of countries.

Hence, it is accurate that we should examine as an example the education systems of Singapore, Japan, Korea, USA and China and monitor them, apart from European Union countries.

These countries have been chosen according to their results across the world.

\subsection{New approaches in education (in terms of structure)}

The changes caused by the globalization process are reflected in a developing community like the EU and affect Turkey as well.

"In the progress reports prepared since 1998; it is noted that Turkey's education system is generally in line with the EU education policies, however Turkey provides lower standards in terms of education services, courses, education personnel and general personnel in comparison with the EU. In addition, there were significant differences between Turkey and EU because of the big lack of education among poor people, poor education opportunities and low participation to the life long learning. It is emphasized that the developments observed every years are very limited. "[13] 
At this point, it is necessary to mention this prominent data network.

Eurydice Network: provides information and analysis on European education systems and policies. It consists of 37 national units located in the 33 countries (EU Member States, EFTA countries, Croatia and Turkey) that are involved in the EU Lifelong Learning program.

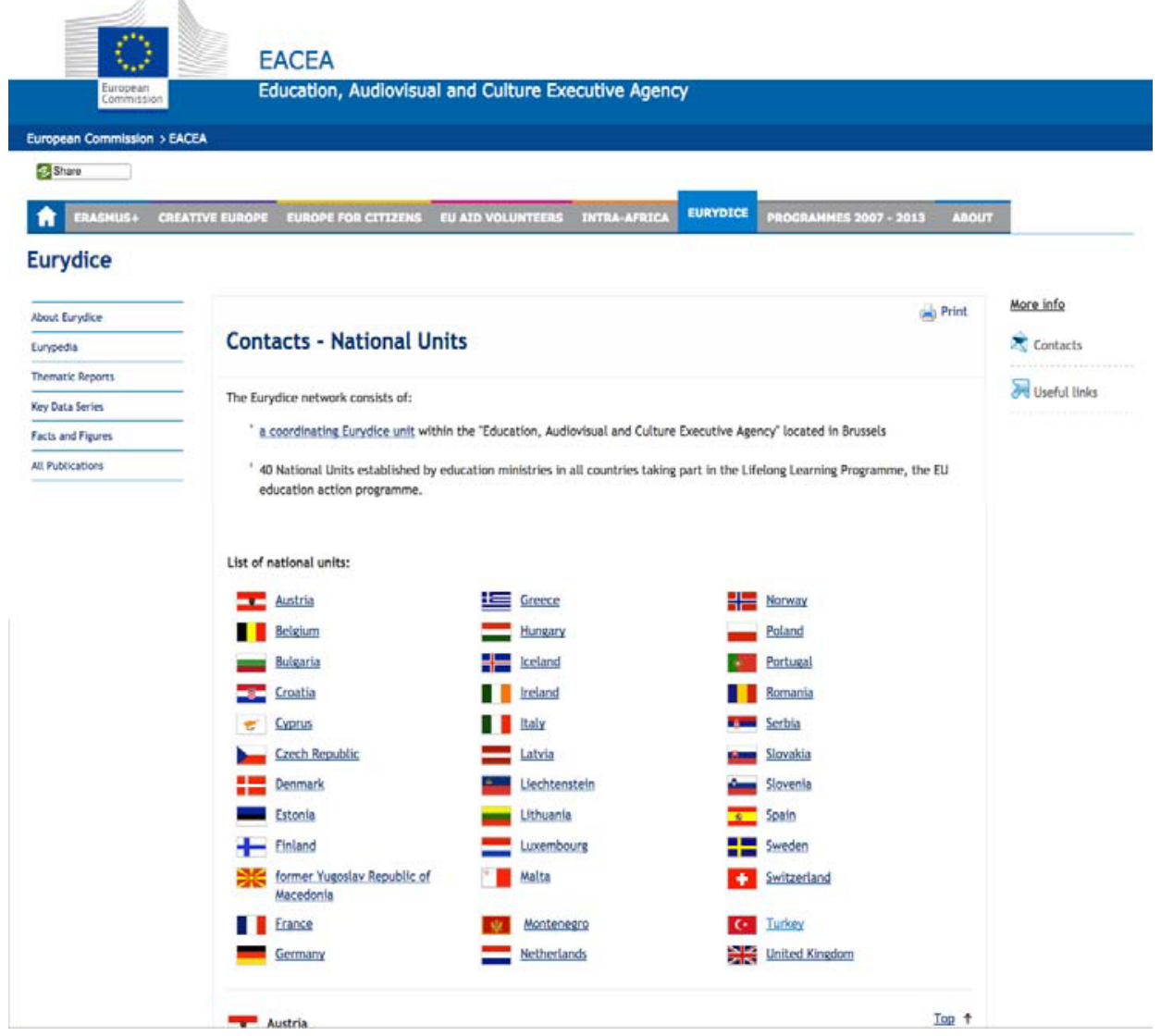

Fig. 1. Eurydice Network providing information and analysis on European education systems and policies

EU Education, Audiovisual and Culture Executive Agency, located in Brussels, is responsible for the coordination of this network.

This agency defines the draft of the education practices and provides a series of online resources. All Eurydice publications are available free of charge at http://eacea.ec.europa.eu/education/eurydice/

Turkey should resolve its problems in quality assurance of the educator training programs and the number of students per educator, etc. in accordance with EU standards.

In the majority of European countries, the total proportion of public spending on education appears to be more than $5 \%$ of GPD.

The process of transition to the information society in developed countries began in the 1980 s and a new global economic structure called as "the information economy" has emerged.

Accordingly, many studies have proven that the "knowledge" is the driving force of economic growth in terms of total factory productivity. 


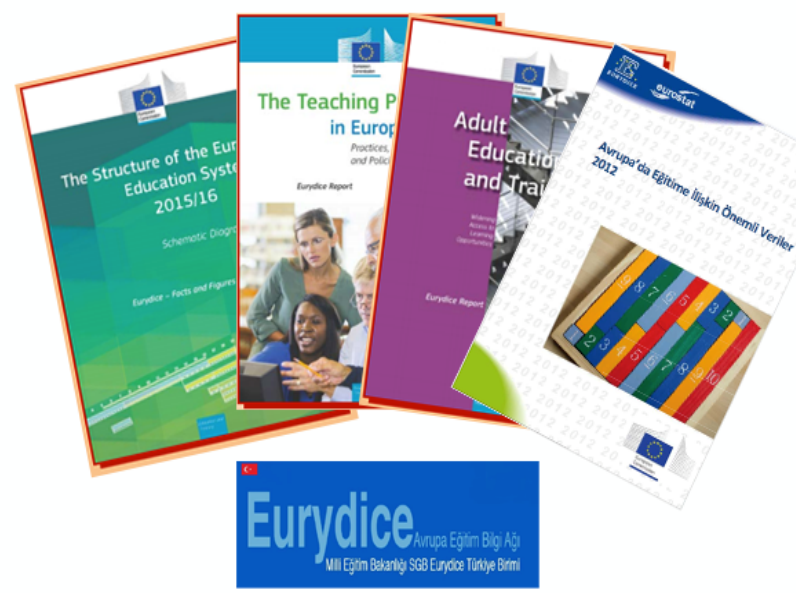

Fig. 2. Examples from EU Eurydice Network sources.

\subsection{New approaches in education (in terms of human factor)}

As we have mentioned before, the name of the society is now called as the 'information society'. Information is constantly and rapidly increasing and spreading. This requires that we review the concepts of adult education, lifelong education, on-the-job training and continuous education.

In European countries, "adult education" is an important subject.

In order to increase the educational success of the adult population, "second chance" programs are created, and formal education procedures are formulated to fulfill the demand. (Figure:3)

However, there is no alternative way in our country.

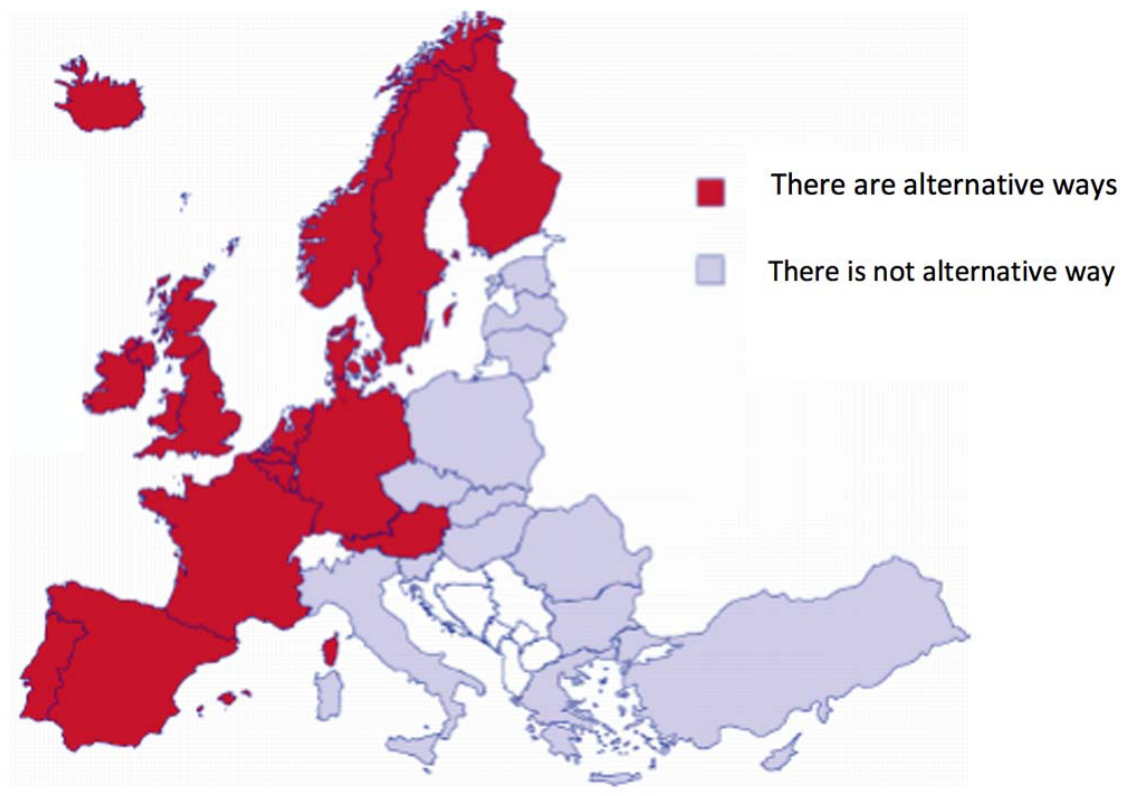

Source: Eurydice

Fig. 3. Higher education alternatives for various candidates in Europe, 2009/10 
On-the-job training and administrator training are important titles that were highlighted.

In Europe, in addition to professional teaching experience, a separate professional management education is required to be a school administrator in many countries.

"Administrator training" is not compulsory in our country.

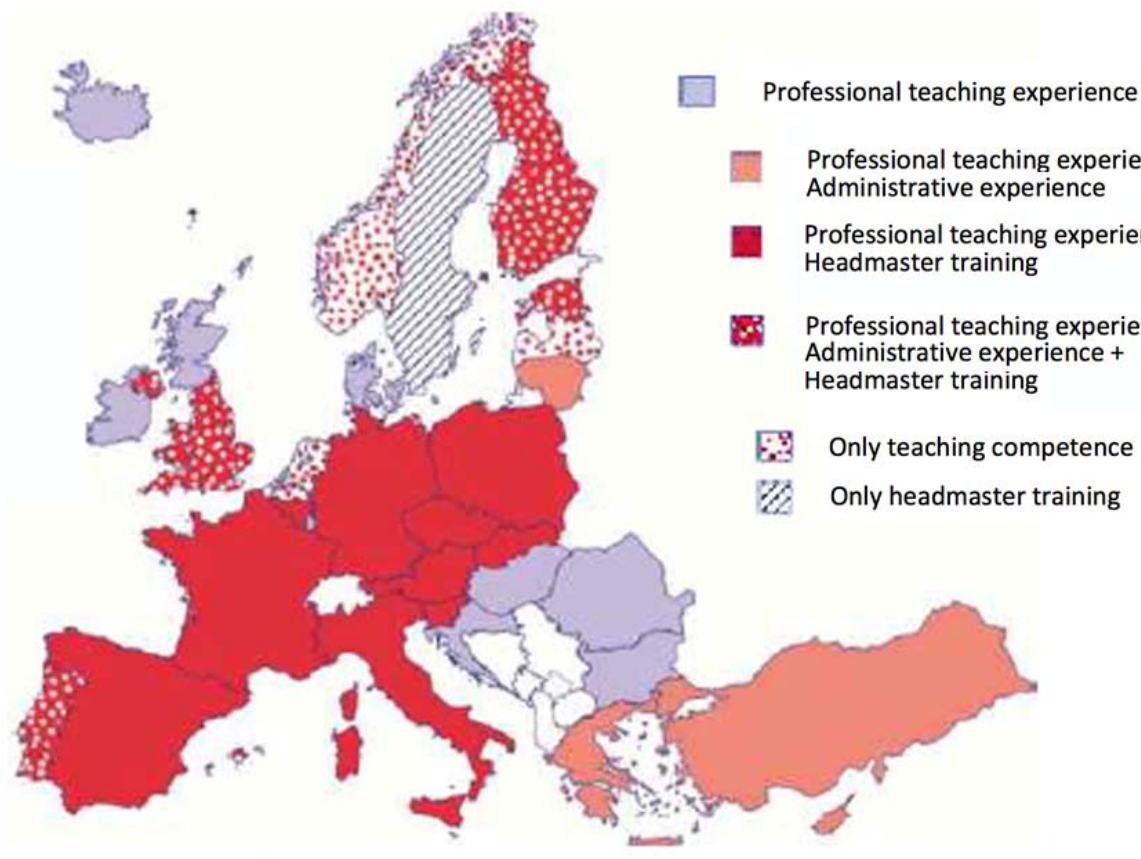

Source:Eurydice

Fig. 4. Professional experience and training required becoming a principal for primary and secondary schools in Europe, 2010/11

Continuing Professional Development is another prominent title for Educators.

According to this research, whose results are presented in Figure 5 and published in Eurydice, $40 \%$ of the school administrators in our country stated that the pedagogical lack of educators has a "very negative" effect on the education.

Continuing Professional Development (CPD) came into prominence in recent years. It is accepted as a mandatory occupation in the educational system of $28 \mathrm{EU}$ countries.

It has been ascertained that the schools must have Continuing Professional Development plans.

In Turkey, Continuing Professional Development exists legally but is not imperative. Unfortunately, schools do not have CPD plans, as they are not compulsory.

Since the educators lack of pedagogical formation and their knowledge is not improved by CPD programs, it is very crucial in order to show the correct attitude against student behaviors and use information and communication technologies more effectively. 


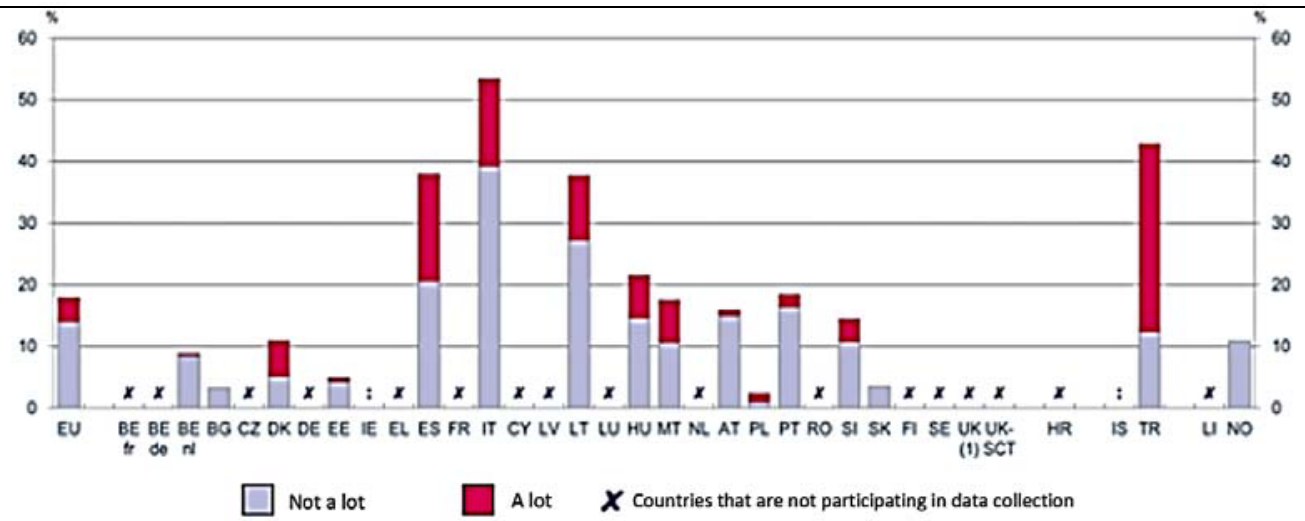

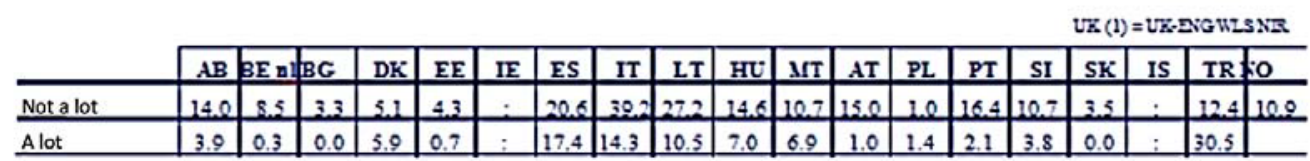

Source: OECD, TALIS 2008 database

Fig. 5. The percentage (\%) of administrators in Turkey who stated that the pedagogical lack of educators has a "very negative" effect on the education, 2008.

The mobility scheme of the educators for foreign education is another important title.

Many European countries have introduced political measures for the EU Lifelong Learning Program (LLP). However, incentive plans to promote the participation of Europe in learning activities of different countries are not very widespread. Unfortunately, Turkey is one of the countries where this plan is not available.

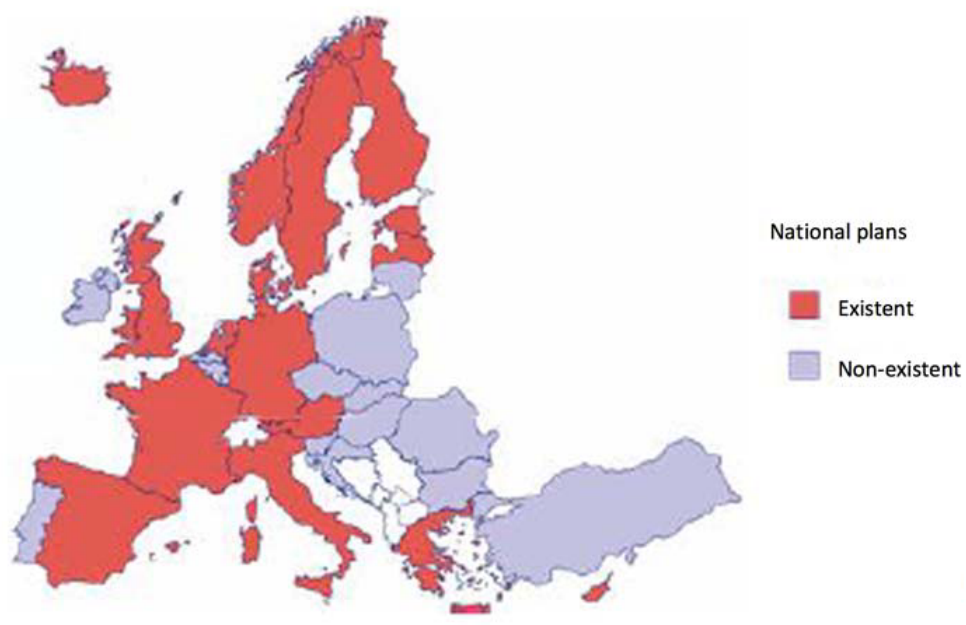

Source:Eurydice

Fig. 6. The existence of foreign education mobility plan for educators, 2011/12

The ratio of Student/Educator is another prominent title.

"In the majority of countries, the ratio of student/educator varies from 10 to 15 students per teacher. Turkey is the only country that exceeds that ratio with 20 students per teacher, equals to $22.1 \%$. The ratio of student/educator is found by dividing the total number of students by the total number of educators, and this should not be confused with the number of students in a single class." [14] 


\section{Conclusion}

Turkey should develop policies to promote the investment of private sector in education in order to approach countries and particularly EU countries that have achieved very goods results in terms of budget spent for education.

The decision should be taken to integrate agriculture, technology, the industry with science and education in our country.

Turkey should increase its investments in developed universities, thus create policies in order to gain a share in the competitive environment in higher education. Accordingly, income sources of higher education should be diversified.

Practices for lifelong learning intended for young population should be increased.

School-recruitment relationship should be prioritized in order to ensure functionality of training programs to be opened for new professions arising based on the technological and scientific developments. In addition, school-industry partnerships should be established in order for vocational and technical education institutions to be able to provide training in accordance with the demands.

New foreign language methods should be developed so that graduates of the primary school may speak at least one foreign language fluently.

Training programs based on occupational standards should be developed so that secondary education may be linked to lifelong education.

We need to ensure that the rate of lifelong learning increases and information and communication technologies become more prevalent in schools.

Particularly the cooperation of primary and secondary schools with families should be ensured.

With the policies that intend to develop entrepreneurial skills of the students, we should encourage the development of entrepreneurial skills of educators and school administrators.

Educators training programs in Turkey should be reviewed in global standards. All teachers (primary-secondary-high school and university) should be given the opportunities to profit from EU's mobility programs for studying abroad.

Researches should be conducted to evaluate the existing policies and programs concerning education supervision and non-formal education in Turkish Education System.

We are aware that all this information and researches are very important. However, it is important to underline this valuable information mentioned as following: "A good system does not guarantee good education output."

That means, we cannot achieve a good result if we fail to achieve our target in a few important parameters of success. Even if the system is good...

As an educator, when we think about our responsibilities, we realize that we need to continuously monitor researches and developments.

When we evaluate successful countries, we realize that their education is based on knowledge and generated other information with new knowledge and that they achieved to reform the educators training.

Despite what has been explained so far, the principal point of this subject is the motivation of educators and their adaptation to the new era where we are living in.

It seems we need to be aware of this critical change as school and educators.

\section{References}

1. Turan, S. "Ögrenen Toplumlara Dogru Avrupa Birligi Egitim Politikalarında Yasam Boyu Ögrenme.” Ankara Avrupa Çalısmaları Dergisi, 5 (1) 2005, 87-98.

2. Gülcan, M. G. (2010). "Avrupa Birligi ve Egitim.” (2. Bask1) Pegem Akademi, Ankara 
3. M. Saglam, F. Özüdogru, F. Çıray, “Avrupa Birligi Egitim Politikaları ve Türk Egitim Sistemine Etkileri”, Yüzüncü Yıl Üniversitesi, Egitim Fakültesi Dergisi. Aralık (2011), Cilt:VIII, Sayı:I, 87-109 http://efdergi.yyu.edu.tr)

4. Aybat Burcu, “Ögretmen 2.0” kitap, Abakus (2016) İstanbul

5. Demirel Özcan, “Gelecek İçin Egitim.”, kitap, Pegem (2012) Ankara

6. Tanrıkulu D. "Yüksekögretime Erisimin Arz ve Giris Kosulları Açısından Degerlendirilmesi ve Türkiye İçin Çözüm Önerileri.”, DPT Uzmanlık Tezi, (2009) Ankara

7. Yavuz Mehmet, Kalkınma Bankası Planlama Uzmanı, "Neden Yüksek Ögretim Reformu" Yüksekögretim ve Bilim Dergisi/Journal of Higher Education and Science, (2012)

8. Yavuz M. "Yüksekögretim Yönetiminde Yasanan Dönüsüm ve Türkiye İçin Alternatif Yönetim Modeli Önerisi.”, Kalkınma Bakanlıgı Uzmanlık Tezi, (2012) Ankara

9. Tanrıkulu D. "Yüksekögretime Erisimin Arz ve Giris Kosulları Açısından Degerlendirilmesi ve Türkiye Için Çözüm Önerileri.”, DPT Uzmanlık Tezi, (2009) Ankara

10. Philippe A., Dewatripont M., Hoxby C., Mas-Colell A., Sapir A. "The Governance and Performance of Universites: Evidence From Europe and the US", Economic Policy, (2010), 7-59.

11. Wissema J.G., "Üçüncü Kusak Üniversitelere Dogru" (çev. Devrim N, Belge T), Özyegin Üniversitesi Yayınları, (2009) İstanbul

12. Erginer Aysun, “Avrupa Birliği egitim Sistemleri” kitap, Pegem, (2006) Istanbul

13. Eurydice Report, 2010b

14. Eurodice, Basic Data on Educators and School Leaders, (2013)

15. OECD, "Education At a Glance" (2010), Paris

16. OECD, "TALIS veritabanı", (2008)

17. Eurodice, “Avrupa'da Ögretmenler ve Okul Liderlerine İliskin Temel Veriler”, (201)3

18. http://eacea.ec.europa.eu/education/eurydice/ 